\title{
O novo Ministro da Justiça
}

\author{
Dr. Ernesto Leme
}

Discurso de saudação ao dr. Vicente Ráo, na visita de despedida á Faculdade de Direito de São Paulo, realizada a 26 de Julho de 1934.

"Senhor professor Vicente Ráo:

A Faculdade de Direito da Universidade de São Paulo sente a mais nobre ufania em receber-vos no dia de hoje.

Partis para o desempenho de uma dificil e honrosissima missão. Mas, antes de iniciardes a magnifica tarefa, que, sem dúvida, realizareis, na pasta que, com tanta felicidade, vos foi confiada, aqui vindes repousar, por um momento, no doce aconchego desta casa, ouvindo bater, febricitantes, os corações de vossos colegas e entre as aclamações, com que vos acolhem os estudantes.

Bem percebeis, nestas vibrações, com que o carinho dos mestres e a admiração dos discipulos vos saúda, a alegria alviçareira com que São Paulo recebe, na pessoa de seu filho dileto, a incumbencia de dar corpo e vida aos principios consignados em nossa nova Carta Constitucional.

Temos, emfim, após tão larga espera e tão grandes sacrificios uma Constituição. Organizada se acha, de acôrdo com ela, o poder federal. Cabe a este, e especialmente, ao detentor da pasta do Interior e Justiça, colocar o pais dentro dos quadros que ela traçou. Essa a missão que o senhor presidente da Republica acaba de vos entregar. Essa a mis- 
são que ha de cobrir de maior lustre o vosso nome e encher de orgulho a esta Faculdade.

Possuis todos os altos predicados exigidos para um perfeito homem de Estado: o talento, a ilustração, o tacto, o elevado criterio. De tudo isso tendes dado sobejas provas, no curso de vossa carreira e essas qualidades vos garantem seguro exito, no desempenho da ardua missão, de que fostes investido.

Não sois um hospede, ademais, na disciplina em que deve ser particularmente versado o ministro a quem cabe tão grande papel, no atual momento. Consagrastes-vos, por largos anos, ao estudo aprofundado do Direito Publico, seguindo todas as transformações operadas, nesse ramo da ciencia juridica, na sociedade contemporanea. $O$ vosso pendor por essa especialidade valeu-vos, em Paris, a amizade de Mirkine Guétzevich, com quem debatestes, por longas horas, êsses problemas. E quando retornastes á patria, reassumindo a vossa cadeira nesta Faculdade, tivestes ensejo de demonstrar, ainda uma vez, na série memoravel de conferencias, do curso de extensão universitaria, o tesouro inestimavel dos vossos conhecimentos sobre o assunto.

Mas, a Assembléa Nacional Constituinte iniciára a sua obra. As associações de juristas se movimentavam, para prestar a sua contribuição á mesma. E o colendo presidente do Instituto dos Advogados de S. Paulo chamou a postos alguns colegas, para o exame do projeto de Constituição. Tive a fortuna de estar entre êsses. E pude, dessa fórma, muito aprender, na vossa companhia.

Tardes inteiras consumimos no estudo do projeto. $\mathbf{E}$ posso dar público testemunho de que, nessa comissão de juristas, ninguem trabalhou mais do que vós. Tinheis elaborado, tambem, o vosso projeto de Constituição. Todos aqueles problemas vos eram familiares. Sobre todos eles haveis meditado demoradamente. Analisastes, calma, detidamente, todos os dispositivos. A vossa opinião era sempre o resultado de madura reflexão e prolongado estudo. Mas, se dos debates havidos, vos convencieis de que a melhor opi- 
nião não era a vossa, de pronto a abandonaveis, para acolher a sugestão que vas parecêra mais acertada. A colaboração do Instituto, de que ora sois digno presidente, foi, assim, em grande parte, produto do vosso esforço.

E' com essa preparação completa que ides assumir a pasta da Justiça, como delegado de S. Paulo, no primeiro govêrno constitucional da segunda Republica.

Pertence-vos a gloria de terdes sido eleito, entre oito milhões de paulistas, como o mais indicado para tão elevada missão. Pesa, por isso mesmo, sobre vós, enorme responsabilidade. S. Paulo inteiro tem os olhos fitos em vossa pessoa e confia na capacidade e no patriotismo de seu grande filho.

Finda a vossa tarefa, aqui vos aguardarão, de braços abertos, os vossos colegas de Congregação e os vossos discipulos. Haveis de voltar coberto de louros, pelos esplendidos serviços que, sem dúvida, prestareis ao país. Mas, esta Faculdade, em que formastes o vosso espirito e em que tanto contribuis agora para a formação do espirito da juventude que aqui passa, coparticipará desse triunfo e ha de reconhecer, como sua propria, a gloria de que se cobrirá o vossc nome.

Senhor professor Vicente Ráo, a Congregação da Faculdade de Direito de S. Paulo vos saúda e espera que tudo fareis, como ministro de Estado, em bem de S. Paulo e do Brasil" 